\title{
TWO NEW RECORDS OF PLAGIOTHECIUM FROM INDIA
}

\author{
A. K. Asthana* and V. Sahu \\ Bryology Laboratory, C.S.I.R. - National Botanical Research Institute \\ Lucknow-226001, India; *E-mail: drakasthana@rediffmail.com
}

(Received 31 March, 2014; Accepted 1 September, 2014)

\begin{abstract}
Govind Wild Life Sanctuary in the Western Himalayas with its diverse vegetation types provides excellent habitats and microclimates for a lush growth of bryophytes. During investigations on the bryophytes of this region Plagiothecium euryphyllum (Cardot et Thér.) Z. Iwats. and P. cavifolium (Brid.) Z. Iwats. have been identified for the first time from India. P. euryphyllum is characterised by bright green to yellowish green plants, irregularly branched, complanate. Central strand developed. Leaves erectopatent, imbricate, ovate oblong, margin entire, acute to acuminate at apex, costa two forked, decurrent with hyaline, rectangular cells. Seta reddish, capsule erect to inclined, while plants of $P$. cavifolium are yellowish green, glossy, prostrate, irregularly branched, branches julaceous. Leaves appressed to stem, closely imbricate, erectopatent, ovate lanceolate, symmetrical, margin minutely dentate at apex, cells at alar region rectangular costa two short. Seta reddish brown, capsule erect, pyriform. A morpho-taxonomic account of above two taxa is provided.
\end{abstract}

Key words: Govind Wild Life Sanctuary, India, Plagiothecium cavifolium, Plagiothecium euryphyllum

\section{INTRODUCTION}

The genus Plagiothecium B. S. G. consists of about 90 species world-wide especially in the temperate zones (Buck and Ireland 1985). Vohra (1974) described a new species of Plagiothecium (P. dehradunense) from India. Gangulee (1980) described 6 species of Plagiothecium from India. Lal (2005) listed 11 taxa of Plagiothecium from India out of which 8 taxa are from the Western Himalayas, 2 from the Eastern Himalayas and 1 from South India. Plagiothecium euryphyllum (Cardot et Thér.) Z. Iwats. was earlier known from Bhutan, China, Japan, Formosa and Korea, while P. cavifolium (Brid.) Z. Iwats. was earlier 
known from Bhutan, China, Europe, Korea, Japan, Nepal Himalayas, North America and Russian Far East. During recent investigations on the bryophytes of Govind Wild Life sanctuary, these two taxa have been identified at places on the way to Talhuti and Kedarkantha (Juda Tal), respectively in this region. Hence these two taxa are new additions to the bryoflora of India.

\section{MATERIALS AND METHODS}

Plant specimens were collected on the way to Kedarkantha, Juda Tal and Talhuti, Govind Wildlife Sanctuary, Uttarakashi district of Uttarakhand, the Western Himalaya, India. The voucher specimens were deposited in the Bryophyte Herbarium, CSIR - National Botanical Research Institute, Lucknow (LWG). The nomenclature, identification and treatment of taxa follow Iwatsuki's revision on Plagiothecium (Iwatsuki 1970).

\section{Taxonomic description}

Plagiothecium euryphyllum (Cardot et Thér.) Z. Iwats. (Figs 1-12)

Plants bright green to yellowish green, glossy, prostrate, irregularly branched, branches $10-18 \mathrm{~mm}$ long and $2-4 \mathrm{~mm}$ wide including leaves, branches creeping to ascending, complanate. Stem rounded in cross section, $0.26-0.32 \mathrm{~mm}$ wide, cortical cells thick walled, 8-16 $\mu \mathrm{m}$ long and 8-12 $\mu \mathrm{m}$ wide, medullary cells $20-40 \mu \mathrm{m}$ long and $16-36 \mu \mathrm{m}$ wide, polygonal, thin walled, central strand developed. Leaves erectopatent, imbricate, ovate oblong, margin entire, acute to acuminate at apex, 1.48-2.4 mm long and 0.8-1 mm wide, apical cells $48-80 \mu \mathrm{m}$ long and 8-12 $\mu \mathrm{m}$ wide, linear rhomboid, median leaf cells 100-140 $\mu \mathrm{m}$ long and 8-12 $\mu \mathrm{m}$ wide, porose, basal cells at alar region rectangular, 20-48 $\mu \mathrm{m}$ long and 16-20 $\mu \mathrm{m}$ wide, costa two forked, extending above middle, leaf base decurrent with hyaline, rectangular cells. Perichaetial leaves $1.5-2 \mathrm{~mm}$ long and $0.48-0.56 \mathrm{~mm}$ wide, costa faintly developed. Perichaetial leaves clasping the seta. Perichaetial leaf cells 100-120 $\mu \mathrm{m}$ long and $8 \mu \mathrm{m}$ wide, linear flexuose, median leaf cells $80-120 \mu \mathrm{m}$ long and $12 \mu \mathrm{m}$ wide, margin entire. Seta reddish, $20-30 \mathrm{~mm}$ long, capsule erect to inclined, oblong-cylindrical, 3-4 mm long and $0.8-1 \mathrm{~mm}$ wide. Peristome teeth $0.56-0.64 \mathrm{~m}$ long, lanceolate, papillose.

Plagiothecium euryphyllum can be differentiated from other species by having broadly acute apex and distinct hyaline alar cells. P. euryphyllum is closely related to $P$. neckeroides, but in the latter species leaf bases are widely decurrent and at the leaf apex propagules or rhizoids are produced. 

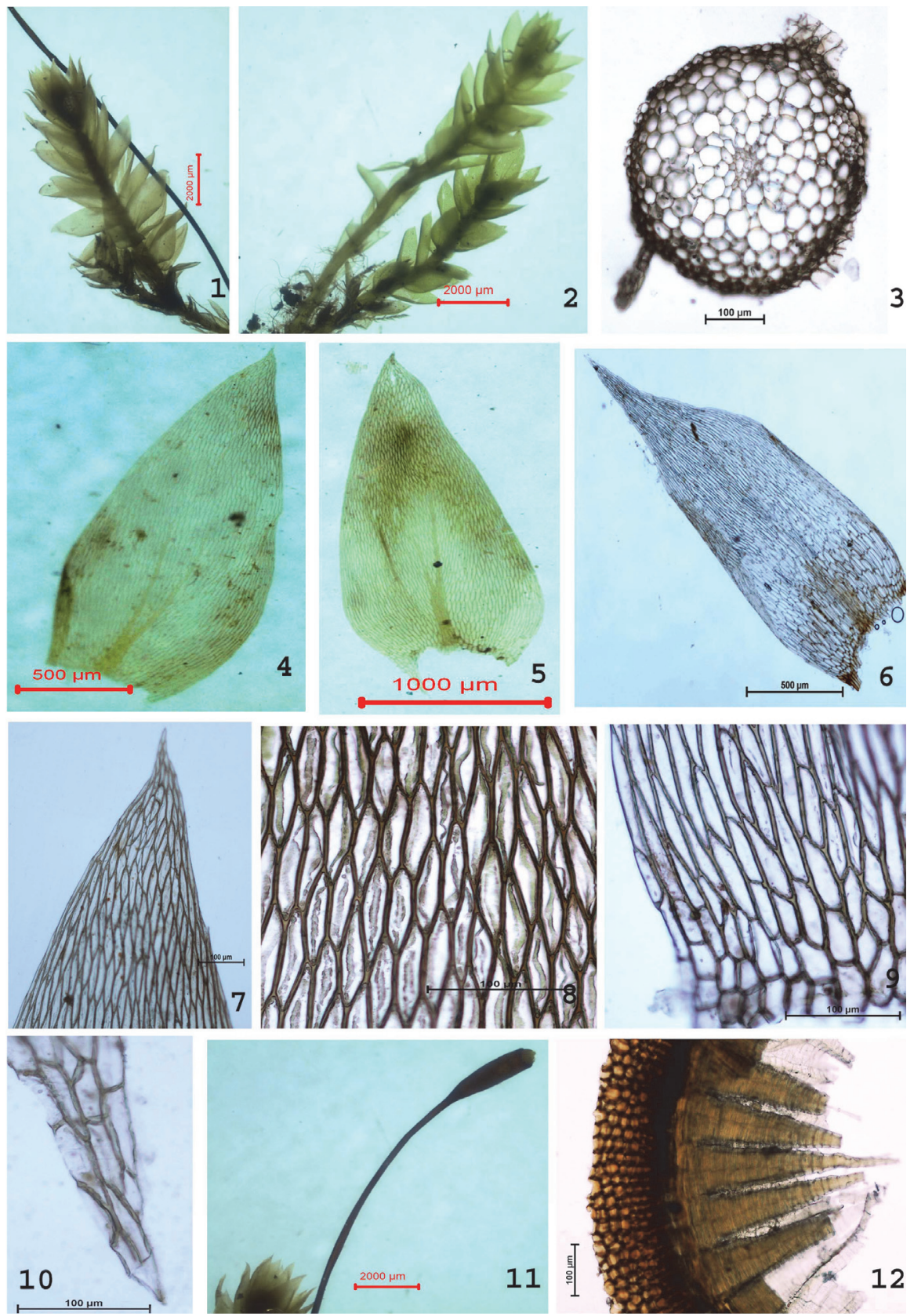

Figs 1-12. Plagiothecium euryphyllum (Cardot et Thér.) Z. Iwats. $-1-2=$ plants; $3=$ cross section of stem; $4-5=$ leaves; $6=$ perichaetial leaf; $7=$ apical leaf cells; $8=$ median leaf cells; $9=$ basal leaf cells; 10 = decurrence of leaf; 11 = capsule; 12 = peristome 
Specimen examined: India, Western Himalayas, Uttarakhand, Uttarakashi, on the way to Talhuti, on soil covered rock. Lat.: $31^{\circ} 04^{\prime} 40.1^{\prime \prime} \mathrm{N}$; Long.: $78^{\circ} 15^{\prime} 04.2^{\prime \prime} \mathrm{E}$; Alt.: ca 2,155 m. Leg.: Vinay Sahu (265048A), 05.04.2013 (LWG).

Distribution: Bhutan, China, Formosa, India, Japan, Korea.
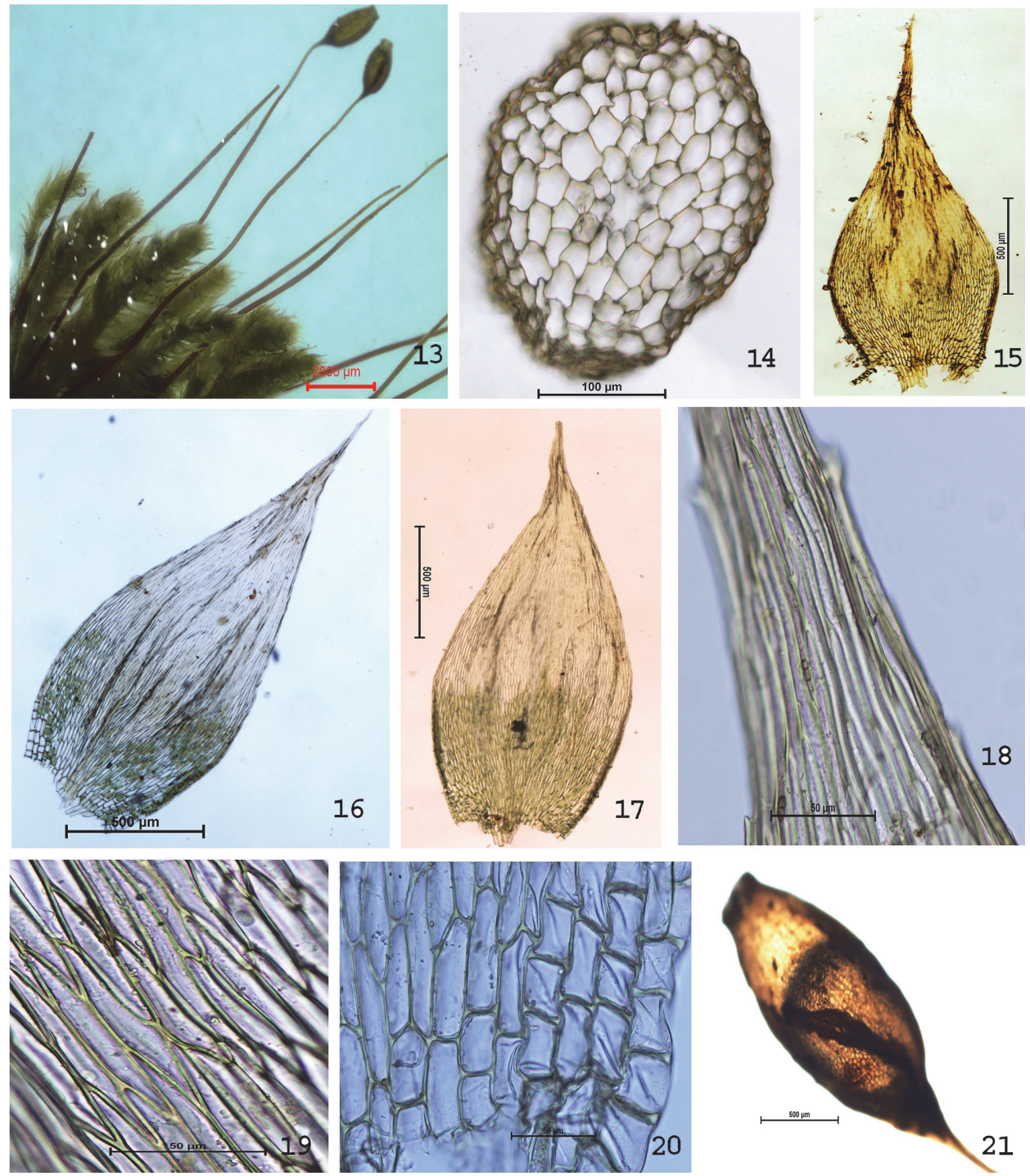

Figs 13-21. Plagiothecium cavifolium (Brid.) Z. Iwats. $-13=$ plant; $14=$ cross section of stem; 15-17 = leaves; 18 = apical leaf cells; $19=$ median leaf cells; 20 = basal leaf cells; 21 = capsule 


\section{Plagiothecium cavifolium (Brid.) Z. Iwats.}

(Figs 13-21)

Plants yellowish green, glossy, prostrate, irregularly branched, branches julaceous, 7-12 mm long. Stems rounded to elliptical in cross section, $0.28 \mathrm{~mm}$ long and $0.24 \mathrm{~mm}$ wide, outer cortical cells thick walled, 16-20 $\mu \mathrm{m}$ long and 8-12 $\mu \mathrm{m}$ wide, polygonal, medullary cells thin walled 32-40 $\mu \mathrm{m}$ long and 28 $\mu \mathrm{m}$ wide, polygonal, central strand present. Leaves appressed to stem, closely imbricate, erectopatent, ovate lanceolate, symmetrical, margin minutely dentate at apex, 2-2.5 mm long and 0.8-1 mm wide, apex acute. Leaf apical cells 80-120 $\mu \mathrm{m}$ long and $8 \mu \mathrm{m}$ wide, linear rhomboid, median leaf cells 100-120 $\mu \mathrm{m}$ long and $8 \mu \mathrm{m}$ wide, at base alar cells differentiated, cells at alar region rectangular, 28-48 $\mu \mathrm{m}$ long and 12-16 $\mu \mathrm{m}$ wide, costa two forked, short. Perichaetial leaves ovate lanceolate, $1.5-1.8 \mathrm{~mm}$ long and $0.32-40 \mathrm{~mm}$ wide, costa absent. Seta reddish brown, 15-17 mm long, capsule erect, pyriform.

Specimens examined: India, Western Himalayas, Uttarakhand, Uttarakashi, on the way to Kedarkantha, Juda Tal, on bark. Lat.: $31^{\circ} 03.116^{\prime}$ N; Long.: $78^{\circ} 11.096^{\prime}$ E; Alt. ca 2,842 m. Leg.: Vinay Sahu (264909B), 05.04.2013 (LWG). - Eastern Himalayas, Nagaland, Kohima road (Kohima-Amgure National Highway), on bark. Alt.: 1,444 m. Leg.: V. Nath (248809), 03.08.2008 (LWG).

Distribution: Bhutan, China, Europe, India, Japan, Korea, Nepal Himalayas, North America, Russian Far East.

$P$. cavifolium differs from other species of the genus in having julaceous to subjulaceous erect branches, closely imbricate concave and symmetrical leaves. Earlier, specimens listed as $P$. cavifolium from the Nagaland by Bansal and Nath (2011) have also been investigated, which actually belong to Campylodontium in which alar cells are very prominent and costa is absent.

Acknowledgements - The authors are grateful to the Director, CSIR - National Botanical Research Institute, Lucknow, India for encouragement and providing the facilities. Financial assistance from CSIR, New Delhi, India (BSC0106) is thankfully acknowledged. Thanks are also due to the authorities of Forest Department, Govind Wild Life Sanctuary, Uttarakhand, India for their help during the visit.

\section{REFERENCES}

Bansal, P. and Nath, V. (2011): Epiphytic bryophytes on Thuja orientalis in Nagaland, NorthEastern India. - Bangladesh J. Plant Taxon. 18(2): 163-167. doi: 10.3329/bjpt.v18i2.9303 
Buck, W. R. and Ireland, R. R. (1985): A reclassification of the Plagiotheciaceae. - Nova Hedwigia 41: 89-125.

Gangulee, H. C. (1980): Mosses of Eastern India and Adjacent Regions. Fasc. 8. - Privately published, Calcutta, India.

Iwatsuki, Z. (1970): A revision of Plagiothecium and its related genera from Japan and its adjacent areas, I. - J. Hattori Bot. Lab. 33: 331-380.

Lal, J. (2005): A checklist of Indian Mosses. - Bishen Singh Mahendra Pal Singh, Dehra Dun, India, $164 \mathrm{pp}$.

Vohra, J. N. (1974): Plagiothecium dehradunense Vohra, a new species of moss from Dehra Dun (U.P.), India. - Bull. Bot. Surv. India 16: 141. 